\title{
PERSPEKTIF PESERTA DIDIK TENTANG KEDAMAIAN DAN RESOLUSI KONFLIK DI SEKOLAH
}

\author{
${ }^{1)}$ Sudaryat Nurdin Akhmad, ${ }^{2}$ Sunaryo Kartadinata, ${ }^{3)}$ Ilfiandra \\ ${ }^{1}$ Dosen Program Studi Bimbingan dan Konseling, Fakultas Ilmu Pendidikan \\ Universitas Pendidikan Indonensia, Bandung, Indonesia \\ Email: sunurakhmad@upi.edu \\ ${ }^{2}$ Dosen Program Studi Bimbingan dan Konseling, Fakultas Ilmu Pendidikan \\ Universitas Pendidikan Indonesia, Bandung, Indonesia \\ Email: sunaryo@upi.edu \\ ${ }^{3}$ Dosen Program Studi Bimbingan dan Konseling, Fakultas Ilmu Pendidikan \\ Universitas Pendidikan Indonesia, Bandung, Indonesia \\ Email: $\underline{\text { ilfiandra@upi.edu }}$
}

\begin{abstract}
Topics examined in this study are peace and conflict resolution in schools in the perspective of learners. The method used is the analysis of narratives. A total of 42 students of class XI used as study participants. Data revealed through autobiographical narratives and interviews and analyzed qualitatively. The results showed that the treatment is less educated than the teacher in the form of verbal and physical punishment as well as conflicts among students in the form of bullying and personal conflicts, an event that otherwise is not peaceful by learners. In conflict resolution with the teachers, they generally prefer to be passive and withdrawn. While the conflict with a friend, in addition, there is also no one dared passive confrontation.

Learners interpret peace more likely in a positive perspective and prioritize peace with self, others, the environment and even with God. Prospects for peace ahead despite pessimistic, but generally they are convinced that with joint efforts for world peace will be achieved.
\end{abstract}

Keywords: Peace, School, conflict resolution, cognitive style

\section{A. PENDAHULUAN}

Sebagai salah satu sistem pendidikan, sekolah memerlukan iklim damai untuk mendukung proses pembelajaran yang berkualitas. Pembelajaran berkualitas, tidak hanya mengajarkan pengetahuan, keterampilan, dan sikap, melainkan mengembangkan dan menumbuhkan rasa cinta, saling pengertian, dan persahabatan. Dengan demikian, memajukan pendidikan dan pembelajaran yang berkualitas identik dengan memajukan kedamaian pada pikiran dan hati peserta didik (Kartadinata, 2014). Kedamaian peserta didik di sekolah dalam kenyataannya tidak mudah diwujudkan. Bahkan akhir-akhir ini indikasi yang berkonotasi tidak damai di sekolah semakin kentara. Berbagai konflik, mulai dari bentuk yang paling sederhana, yakni perilaku verbal, hingga kepada kekerasan yang lebih serius berdimensi fisik berupa tawuran, penganiayaan, bahkan hingga pembunuhan telah dilakukan oleh beberapa peserta didik di sekolah (Joseph, 2012).

$$
\text { Fenomena tersebut tampak }
$$

kontradiktif dengan esensi pendidikan sebagai upaya normatif untuk mendewasakan peserta didik. Hal tersebut juga bertentangan dengan kesepakatan World Education Forum di Dakar tahun 2000, bahwa pendidikan diharapkan mampu merespon tantangan di abad ke-21, yaitu: (1) seluruh generasi muda dan orang dewasa diharapkan memiliki akses yang sama terhadap belajar dan program kecakapan hidup yang lainnya; (2) meningkatkan mutu pendidikan dan hasil belajar, khususnya dalam aspek literasi, numerikal dan kecakapan hidup utama; (3) meningkatkan saling pengertian, kedamaian, dan toleransi dalam rangka 
mencegah kekerasan dan konflik, serta mengubah tatapikir masyarakat untuk menekan perilaku konflik atau kekerasan (Castro \& Galace, 2008). Transformasi ini diharapkan dapat membangun kesadaran dan pemahaman, mengembangkan kepedulian dan menantang tindakan pribadi dan sosial yang akan memungkinkan orang untuk hidup, berhubungan dan menciptakan kondisi dan sistem yang dapat mengaktualisasikan antikekerasan, keadilan, kepedulian terhadap lingkungan dan nilai-nilai kedamaian.

Menyadari demikian pentingnya kondisi damai di sekolah, para peneliti telah melakukan kajian tentang makna, hakekat, dan ragam upaya mengembangkan sekolah damai. Penelitian tersebut umumnya berfokus pada masalah kekerasan langsung atau tidak langsung, basis pengetahuan tertentu, perangkat norma keahlian, serta orientasi nilai yang ingin dikembangkan (Reardon, 1988). Pada perkembangan berikutnya, orientasi teoretik kedamaian yang semula bersumber dari negative peace dimana kedamaian dimaknai sebagai ketidaaan perang atau kekerasan secara fisik, mulai bergeser ke positive peace dimana kedamaian dimaknai sebagai terciptanya hubungan noneksploitatif antarmanusia dan manusia dengan alam (Mische dalam Reardon, 1993). Mulai tahun 2016, menurut The Centers for International Business Education and Research (CIBER), kajian kedamaian berfokus pada isu "the business peace" yang diusung sebagai topik utama dalam rangka memenangkan kompetisi pasar global dan meningkatkan bisnis pendidikan internasional (Kelley School of Business, 2016).

\section{B. KAJIAN LITERATUR}

Pola studi kedamaian yang dilakukan, pada awalnya berfokus pada analisis komunitas dibanding individu dan faktor-faktor determinan kedamaian dalam perspektif keilmuan tertentu. Pola studi seperti itu belum bisa menggambarkan inner peace secara individual. Kini, riset kedamaian menjadi lebih berdimensi transdisiplin (Mandoza, Valenzuela, \& Guillen, 2013) dan mengkaji kedamaian dalam perspektif positif dengan menggunakan ragam pendekatan riset inovatif. Tekanannya lebih pada dimensi kedamaian individu dibanding komunitas dengan menggunakan pendekatan kualitatif. Salah satu pendekatan kualitatif yang kini sedang trend digunakan dalam studi sekolah aman dan damai adalah narrative case study (Syrjalainen, Jukarainen, \& Kaupinmaki, 2015, p. 61). Melalui analisis narasi sejarah individu tentang suatu peristiwa terkait isu kedamaian, memungkinkan diketahui secara otentik. Begitu juga keterampilan diri individu dalam membangun kedamaian dapat dielaborasi secara natural. Individu-individu yang memiliki pribadi damai sangat memungkinkan membentuk komunitas yang damai pula. Mengacu pada kecenderungan kajian konsep dan pendekatan studi kedamaian, penelitian ini dimaksudkan untuk melakukan kajian naratif perspektif peserta didik tentang kedamaian dan dan resolusi konflik di sekolah.

Makna kedamaian positif yang menekankan pada terciptanya hubungan noneksploitatif sebagamana diungkapkan Mische (dalam Reardon, 1993) mengandung makna keadilan dan kesetaraan bagi semua. Keadilan dan kesetaraan merupakan dasar untuk hidup bersama dalam damai dan harmoni (UNESCO-APNIEVE, 2000). Gagasan tersebut mengelaborasi ekspresi kedamaian secara positif dari perspektif budaya (Sheriff \& Swigonski, dalam Kartadinata, 2015). Lebih lanjut Kartadinata (2015) menegaskan bahwa kedamaian merupakan kondisi optimum keadaan damai yang dinamis dan berdaya adaptasi secara adekuat terhadap perubahan lingkungan. Kondisi ini terjadi 
pada individu yang akan menumbuhkan kedamaian diri, sosial, serta bangsa dan negara. Penelitian yang dilakukan oleh Kartadinata, et al. (2015) di Kota Bandung sebagai salah satu tempat yang berada di tataran budaya Sunda, menemukan konfigurasi nilai kearifan lokal kedamaian dalam budaya Sunda, esensinya terletak pada nilai budaya yang menjalani kehidupan dan penghidupan dalam hubungannya dengan Tuhan, hubungan manusia sebagai pribadi, hubungan manusia dengan sesama manusia dan hubungan manusia dengan alam. Lokus eksistensi ditandai oleh relasi yang harmonis antarelemen diri. Harmoni menjadi orientasi hidup orang Sunda yang kedalaman maknanya melebih terminologi damai dan tidak menempatkan salah satu sebagai sentrum melainkan menjadi satu keutuhan. Perspektif relasi dengan diri pribadi orang Sunda orientasi hidupnya ialah "hirup bagja, aman, tengtrem, ngahenang-ngahening, luhur darajat, ngeunah angeun ngeunah angen, sampurna dunya aherat". Sebagai komparasi kultural, dalam penelitian tersebut juga terungkap bahwa masyarakat Finlandia secara konsisten mempertahankan kesetaraan dan kerja sama meskipun mereka tetap merupakan masyarakat individualistik. Keberhasilan Finlandia dalam mewujudkan masyarakat yang damai melalui sistem pendidikan, didukung oleh pengembangan berbagai niai seperti prestasi tanpa kompetisi horizontal, kepercayaan diri, tanggung jawab, toleransi, trust, kebebasan, dan demokrasi (Kartadinata, et al., 2015).

Budaya damai berbeda dengan pendidikan kedamaian. Menurut Bedir \& Aslan (2013) pendidikan kedamaian mengacu pada upaya membangun hidup dalam damai di antara kelompok yang memiliki perbedaan yang mendorong individu untuk menyelesaikan konflik secara lebih kreatif dan tanpa kekerasan yang pada akhirnya akan menguatkan keterampilan individu dalam menjalani kehidupannya. Damai merupakan hasil dari proses belajar dan untuk dapat menyadari makna dan proses tersebut maka sangat penting untuk melakukan proses transfer pada siswa (Mayer \& Furlong, 2010). Semantara itu, pendidikan kedamaian dalam konsepsi UNICEF sebagaimana dilaporkan oleh Fountain (dalam Kartadinata, et al., 2015, p. 9) mengacu pada proses memajukan pengetahuan, keterampilan, sikap, dan nilai-nilai yang dibutuhkan untuk menghasilkan perubahan perilaku yang memungkinkan peserta didik mencegah terjadinya konflik dan kekerasan baik yang terselubung maupun yang nyata dan terstruktur, menyelesaikan konflik dengan damai, dan untuk menciptakan kondisi yang kondusif bagi perdamaian baik dalam tingkat intrapribadi, antarpribadi, antarkelompok, nasional, maupun internasional.

Terciptanya suasana damai, pada hakekatnya ditentukan oleh bagaimana strategi yang digunakan individu dalam resolusi konflik dan permasalahan yang terkait dengan diri sendiri, orang lain, dan lingkungan komunitas. Resolusi pada hakekatnya adalah pengambilan keputusan yang melibatkan aspek kognisi seseorang. Dalam upaya menerima, memikirkan dan memecahkan masalah serta memahami lingkungannya, individu senantiasa menggunakan pendekatan tertentu yang relatif menetap. Pendekatan tersebut oleh para ahli (Keen,1973; McKenney \& Keen, 1974; Botkin, 1974; Goldstein; 1990; Aiken, 1997; Healy, Harkins, \& Ray, 2010; von Wittich \& Antonakis, 2011) disebut gaya kognitif (cognitive style). Gaya kognitif merupakan salah satu mekanisme kognitif yang berperan penting dalam menentukan suatu perilaku, terutama perilaku agresif (Huesmann \& Guerra, 1977; Guerra, Boxer, \& Kim, 2005; Carpenter, 2012; Calvete \& Orue, 2010) yang sangat berpotensi pemicu peristiwa tidak damai. Sehubungan itu, kajian tentang bentuk perilaku tidak damai dalam perspektif peserta didik akan lebih 
bermakna kalau disertai pengkajian gaya kognitifnya.

Uraian tentang fenomena dan telaahan literatur tentang kedamaian, pendidikan kedamaian, dan resolusi konflik yang telah dipaparkan tersebut menjadi landasan untuk dilakukannya studi naratif tentang kedamaian dan resolusi konflik di sekolah dalam perspektif peserta didik. Kajian resolusi konflik dihampiri dari gaya kognitif peserta didik

\section{METODE PENELITIAN}

Desain penelitian yang digunakan adalah cross sectional dengan pendekatan kualitatif jenis narrative case study kategori analysis of narratives (Polkinghorne dalam Syrjlainen, et al., 2015, p. 61). Penelitian naratif yang dilakukan adalah proses deskripsi pengalaman kehidupan peserta didik secara individual terkait konotasi tidak damai. Data penelitian dikumpulkan dari cerita yang ditulis sendiri oleh peserta didik secara anonim. Alur cerita tersebut mendeskripsikan pengalaman masa lampau peserta didik terkait dengan konotasi tidak damai di sekolah yang sangat mengganggu kedamaiann dirnya dan direfleksikan dalam bentuk tulisan. Untuk memperjelas tema, konteks, kronologis, tokoh, dan respon terhadap situasi tidak damai, maka tulisan itu didiskusikan dengan dan direvisi ulang oleh peseta didik sehingga menjadi tulisan yang memenuhi syarat sebagai sebuah story yang dapat dianalisis lebih lanjut.

Instrumen yang digunakan untuk mengumpulan data adalah panduan analisis narasi untuk setiap peserta didik sehingga dapat diperoleh informasi yang jelas tentang tema, konteks, kronologis, tokoh, dan respon terhadap situasi tidak damai. Untuk memperoleh informasi yang lebih komprehensif dan mendalam mengenai cerita kejadian berkonotasi tidak damai yang telah ditulis peserta didik, dilakkan wawancara dengan menggunakan pedoman wawancara. Hasil wawancara ini dikonversi menjadi transkrip dalam bentuk tulisan sehingga mudah dibaca dan dikaji ulang lebih lanjut.

Partisipan penelitian ini adalah peserta didik kelas XII pada salah satu SMA Negeri di Kota Cimahi sebanyak 42 orang. Penentuan partisipan dilakukan dengan accidental sampling untuk data naratif dan secara sukarela untuk wawancara. Agar memperoleh informasi yang diperlukan, pada proses pengumpulan data terlebih dahulu diberikan penjelasan bagaimana cara menulis narasi. Dalam suatu narasi harus secara rinci mengungkapkan apa yang dirasakan sebagai situasi tidak damai, bagaimana kronologis kejadiannya, dan bagaimana respons peserta didik terhadap situasi tersebut. Penulisan narasi sekitar 500 kata dilakukan di ruang kelas dan menghabiskan waktu rata-rata 30-45 menit. Sementara itu, proses wawancara terhadap partisipan secara sukarela, dilakukan satu hari setelah mereka mengumpulkan narasi dan dilakukan di sekolah dengan fasilitasi guru bimbingan dan konseling. Partisipan yang bersedia mengikuti wawancara adalah 27 orang.

Data penelitian dianalisis secara kualitatif berdasarkan tipe kasus secara individual. Seluruh protokol data naratif dibaca satu persatu kemudian diberi koding pada lokasi tulisan yang menyatakan tema, kontek, alur, kronologi kejadian, dan resolusi terhadap tema. Selanjutnya dilakukan ketegorisasi dan penarikan esensi atas setiap kategori. Analisis data ini dilakukan terhadap dokumen narasi dan transkrip hasil wawancara.

\section{HASIL DAN PEMBAHASAN}

Berdasarkan analisis terhadap narasi dan transkrip wawancara, ditemukan empat tema spesifik yang relevan untuk dianalisis, yaitu: (1) bentuk peristiwa tidak damai yang dialami peserta didik di sekolah, (2) resolusi konflik di sekolah, (3) perspektif peserta didik tentang makna, ciri-ciri, serta tanggung jawab memelihara 
kedamaian, dan (4) prospek kedamaian di masa depan. Hasil penelitian dan diskusi terkait keempat tema tersebut dikemukakan dalam uraian berikut.

\section{Bentuk Peristiwa Tidak Damai yang Dialami Peserta Didik di Sekolah}

Berdasarkan analisis terhadap transkrip wawancara, diperoleh informasi bahwa peristiwa konotasi tidak damai di sekolah dipicu oleh dua sumber utama, yaitu pihak guru $(50 \%)$ dan sesama peserta didik $(43 \%)$. Hanya sekira $7 \%$ yang dipicu oleh kondisi kesehatan dan kebijakan sekolah.

narasi peserta didik secara individual dan

Tabel-1 Pendapat Partisipan tentang Konteks dan Bentuk Peristiwa Tidak Damai di Sekolah

\begin{tabular}{|c|c|c|}
\hline No. & Konteks & Peristiwa \\
\hline 1. & $\begin{array}{l}\text { Guru dalam } \\
\text { proses } \\
\text { pembelajaran }\end{array}$ & $\begin{array}{l}\text { 1. Cara mengajar guru Fisika tidak pernah menjelaskan materi pelajaran, hanya menyuruh } \\
\text { membeli buku (P1) } \\
\text { 2. Dikeluarkan dari kelas oleh guru Fisika karena tidak bisa mengerjakan soal dan kesal } \\
\text { karena kalau ulangan hanya satu soal (P15) } \\
\text { 3. Kurang terampil mengajar Fisika, mengancam memberikan nilai di bawah KKM (P4). } \\
\text { 4. Guru mengajar Olah raga ala militer dan mengumbar perkataan menyingung perasaan (P5) } \\
\text { 5. Respon Guru BK yang menyepelekan potensi dan kemampuan masuk PT Negeri, padahal } \\
\text { termasuk tiga besar di kelas (P6) } \\
\text { 6. Tugas yang diberikan guru memberatkan (P11) } \\
\text { 7. Guru sejarah berceramah agama di kelas tentang hal-hal yang kontroversial (P14) } \\
\text { 8. Diperlakukan tidak menyenangklan oleh guru Fisika di depan kelas karena tidak bisa } \\
\text { mengerjakan soal tugas. Saat itu guru memegang tangan kiri saya sambil berkata "Nih } \\
\text { anak-anak contoh gerak harmonik sederhana" (P17) } \\
\text { 9. Tidak diperbolehkan mengikuti praktikum TIK tanpa alasan yang jelas, ketika bertanya } \\
\text { alasannya malah guru berbalik marah (P18) } \\
\text { 10. Diberi label sebagai anak yang suka remedial oleh guru Matematika (L8) }\end{array}$ \\
\hline 2. & $\begin{array}{l}\text { Guru dalam } \\
\text { memberikan } \\
\text { hukuman }\end{array}$ & $\begin{array}{l}\text { 1. Wali kelas yang tidak berpihak pada peserta didik (P7, P16) } \\
\text { 2. Guru mencukur rambut saya di depan kelas padahal rambut saya baru dipotong (P9) } \\
\text { 3. Dihukum oleh guru Matematika karena lupa membawa buku catatan: Scoat jump } 20 \text { kali } \\
\text { di sepan kelas (P2) } \\
\text { 4. Contekan kelas di papan tulis saat ulangan, diketahui oleh guru. Semua peserta didik } \\
\text { dimarahi (P3) } \\
\text { 5. Sakit hati oleh wali kelas karena dianggap menyalahgunakan SPP karena tiga bulan telat } \\
\text { dibayar padahal orang tua sedang kesulitan uang. (P12) } \\
\text { 6. Dihukung secara fisik oleh guru Bahasa Inggeris karena kesalahan yang dibuat peserta } \\
\text { didik lain (P19) } \\
\text { 7. Guru Matematika (laki-laki) marah dan mencaci maki dengan kata-rata tidak pantas } \\
\text { berdalih atas nama agama serta menghukum secara fisik di hadapan teman-teman dalam } \\
\text { kelas. Penyebabknya adalah karena secara kebetulan guru tersebut berpapasan dengan } \\
\text { saya di jalan ketika saya setelah pulang sekolah disuruh segera oleh orang tua untuk } \\
\text { membeli makanan. Saat itu saya mengendarai motor hanya berpakaian celana pendek dan } \\
\text { kaos oblong. Sementara saya kalau sekolah memakai jilbab padahal saya sebetulnya } \\
\text { merupakan peserta didik kesayangan guru tersebut di sekolah (P 20) } \\
\text { 8. Dimarahi guru Bahasa Indonesia di tempat umum karena saya tidak menyapanya ketika } \\
\text { berpapasan. Meski sudah minta maaf karena saya tidak melihatnya, guru tersebut } \\
\text { marahnya terus menerus dengan kata-kata yang tidak pantas (P21) }\end{array}$ \\
\hline 3. & $\begin{array}{l}\text { Sesama } \\
\text { peserta didik }\end{array}$ & $\begin{array}{l}\text { 1. Diserang kakak kelas sesama perempuan karena laki-laki yang mereka senangi menjadi } \\
\text { pacar saya (P10, L1, L4) bentrok terselubung (L5), disebut Princes sekolah (L12) } \\
\text { 2. Putus dengan pacar dan tidak percaya pada orang lain (L16) } \\
\text { 3. Berteman dengan laki-laki yang disenangi oleh banyak teman perempuan kemudian } \\
\text { dikucilkan oleh teman (L17) } \\
\text { 4. Bentrok antara jurusan IPA dan IPS dalam lingkungan sekolah (L 3) } \\
\text { 5. Merasa diisololasi teman sekelas (L6, L8) dan dibenci teman (L11) } \\
\text { 6. Perlakuan tidak menyenangkan dari sesama teman perempuan (L7) } \\
\text { 7. Bullying dari teman sekelas (L9, L13) } \\
\text { 8. Direbut pacar oleh teman sesama laki-laki (L15) }\end{array}$ \\
\hline & & 9. Diperdaya teman sehingga konflik dengan guru (L14) \\
\hline 4. & Pribadi & $\begin{array}{l}\text { 1. Menderita sakit parah menjelang waktu ujian } \\
\text { 2. Aturan sekolah tidak tersosialisasikan secara utuh dan sanksi diberikan secara tiba-tiba }\end{array}$ \\
\hline
\end{tabular}


Keterangan: Nomor kode partisipan penelitian di belakang setiap pernyataan, huruf $\mathrm{P}$ bersumber dari guru dan L bersumber dari sesama peserta didik. Sedangkan angka menunjukkan nomor partisipan.Semua pernyataan itu adalah yang ditulis oleh partisipan dalam narasi atau dikatakan saat wawancara

Tabel 1 mengindikasikan bahwa pembelajaran yang tidak berkualitas, pemberian hukuman secara fisik, dan pernyataan kemarahan guru dalam bahasa yang tidak mendidik, merupakan sumber utama dari ragam peristiwa tidak damai yang dirasakan peserta didik di sekolah. Manakala dikaitkan dengan esensi pendidikan sebagai upaya normatif, temuan penelitian ini amat memprihatinkan. Alihalih dapat mengembangkan pembelajaran yang mendidik, dalam mengajar pun para guru masih jauh dari yang seharusnya. Materi pelajaran tidak dipahami peserta didik, banyak tugas dan sulit dikerjakan, dan melakukan evaluasi hasil belajar secara tidak tepat. Bagaimana para guru itu mengajar, antara lain dapat disimak dari ungkapan peserta didik sebagai berikut:

“... beliau merupakan guru yang bisa dibilang membuat siswa-siswanya tidak nyaman, tidak suka padanya. Mengapa? Tentu karena perannya yang kurang sebagai seorang guru.

Selama pembelajaran ... siswa-siswa yang diajar olehnya hanya diminta menghafalkan lagu "Esok Lebih Baik" yang mana lagu itu merupakan lagu yang dibuat oleh Pak ... yang katanya lagu penyemangat, lalu membeli lembar unnsur-unsur kimia periodik ... Buku 1000 bank soal ... lalu diminta menyampul buku tulis seragam satu kelas yang mana hanya diminta membelinya. Tapi selebihnya yang menyangkut Pak ... mengajarlan materi pelajaran di sekolah, itu tidak ada" (P1).

Pendapat peserta didik lainnya tentang guru yang mengajar adalah sebagai berikut, "Beliau baik. Beliau juga sangat cerdas. Namun, beliau kurang terampil dalam membagi ilmunya ... sehingga penulis dan kawan-kawan kesulitan dalam memahami pelajaran" (P4). Salah kaprah guru dalam mengajar juga teramati dari narasi peserta didik yang memberi judul tulisannya "Sejarah atau Khutbah" (P14). Pernyataan lainnya yang menarik adalah sebagai berikut: “ ... bagi saya, guru yang mengajar ... membuat diri saya menjadi down dan tidak bergairah untuk mengikuti jam pelajarannya ... ketika ujian, soalnya hanya satu, jika salah mendapat nilai 0 dan jika betul 100" (P15).

Hal lain terkait konteks guru yang menyebabkan peserta didik tidak damai adalah tutur kata yang tidak mendidik dan tidak pantas diucapkan oleh pendidik seperti tampak dalam narasi sebagai berikut:

"Mengapa kita begitu stress, . guru ini mengajarnya seperti ngajar militer. Latihan fisik, berbaris dan berlari.

Ketika disuruh lari, jika ada yang lemes pasti ada siswa-siswa yang didorong dan dikatain dengan kata-kata 'kamu manusia perpenyakitan, kamu manusia bodoh, kamu manusia lemah' seperti itu" (P8)

Dilihat dari tata kelola kelas, tampaknya para guru cenderung reaktif. Begitu peserta didik memunculkan perilaku yang menurutnya tidak diharapkan maka langsung direspon secara agresif, baik dengan kata-kata maupiun reaksi fisik. Hasil penelitian nafratif yang dilakukan Honkasilta, Vehkakoski, Vehmas (2016) di Finlandia menunjukkan bahwa guru yang menerapkan strategi manajemen kelas reaktif telah menjadikan peserta didiknya selalu menangis. Padahal idealnya guru harus mengambil peran memimpin dalam menjamin keadilan sosial dan kedamaian bagi peserta didik di sekolah (Joseph, 2012).

Peristiwa tidak damai yang dialami peserta didik terkait dengan konteks teman sebaya di sekolah, dalam penelitian ini mengkerucut pada bullying dan koflik 
karena mamsalah pacaran. Temuan penelitian ini sejalan dengan penelitian Cross (2011) di Australia. Data yang diperoleh secara nasional tersebut menunjukkan bahwa bullying menjadi masalah yang sangat mengkhawatirkan. Bullying dan konflik personal pesefrta didik di sekolah juga terjadi karena kepemimpinan guru kurang memberikan perhatian atas berbagai masalah yang dihadapi siswanya (Joseph, 2012). Apabila dikaitkan dengan Glasser's Theory of Choice (Honkasilta, Vehkakoski, Vehmas, 2016, p. 107), bahwa seseorang individu akan mengontrol perilaku mereka sendiri dan bersedia untuk patuh hanya jika kebutuhan mereka terpenuhi, maka bullying merupakan salah satu manifestasi dari tidak terpenuhinya kebutuhan.

\section{Resolusi Konflik di Sekolah}

Berdasarkan hasil analisis naratif, respons peserta didik atas peristiwa tidak damai relatif seragam. Pertama, ketika konteks tidak damai bersumber dari guru, resolusi yang dilakukan adalah: (1) menghindar dan pasif dalam aktivitas pembelajaran, (2) melaporkan peristiwa pada wali kelas, orang tua, dan guru BK, (3) menyalahkan guru dan penerapan peraturan sekolah yang tidak jelas, dan (4) memboikot pembelajaran. Kedua, ketika konteks tidak damai bersumber dari sesama peserta didik, resolusi yang dilakukan adalah: (1) bersikap masa bodoh dan tidak menanggapi, (2) berdiam diri dan menghindar terlibat dalam konflik, dan (3) melawan dan minta klarifikasi secara lisan.

Resolusi yang dipilih peserta didik dalam menghadapi peristiwa tidak damai pada hakekatnya melibatkan kemampuan memecahkan masalah. Dalam upaya menerima, memikirkan dan memecahkan masalah serta memahami lingkungannya, individu senantiasa menggunakan pendekatan tertentu yang relatif menetap. Pendekatan tersebut oleh para ahli (Keen,1973; McKenney \& Keen, 1974; Botkin, 1974; Goldstein; 1990; Aiken,
1997; Healy, Harkins, \& Ray, 2010; von Wittich \& Antonakis, 2011) disebut gaya kognitif (cognitive style). Merujuk pada teori mutakhir yang digagas oleh Kirton gaya kognitif merentang dari dua kutub, yakni adaptif-inovatif (von Wittich \& Antonakis, 2011), Individu adaptif cenderung compliant, metodologik, bijaksana, disiplin, konpormis, pemalu, cenderung ragu, sensitif terhadap orang, menghindari risiko, dan dogmatis. Sementara itu, inovator cenderung bersikap tegas, tidak praktis, tidak konvensional dalam pemikiran, kurang disiplin, menghargai konsensus, nonkonformis, berani menggagas, tanpa ragu, dan tidak sensitif terhadap orang, mencari risiko, fleksibel, dan kasar.

Manakala dihubungkan antara resolusi yang dilakukan peserta didik dengan teori gaya kognitif, maka diperoleh penjelasan bahwa gaya kognitif yang mereka gunakan secara individual ada yang cenderung ke adaptif dan ada yang ke inovatif. Mereka yang memilih diam dan mengalah lebih cenderung adaptif sedangkan mereka yang melawan dan konfrontasi cendnenrung memiliki gaa kognitif inovatif.

Adaptif-inovatif bukanlah suatu dikhotomis melainkan harus dikolaborasikan karena pengambilan keputusan merupakan kombinasi setiap gaya kognitif dengan coping behavior. Semakin besar kesenjangan antara gaya kognitif antarindividu, semakin sulit untuk berkolaborasi, berkomunikasi, dan memecahkan masalah. Sebuah bridger, yakni pihak yang membantu memfasilitasi komunikasi dan kerja sama antara adapter tinggi dan inovator yang tinggi sangat diperlukan. Berkenaan dengan hal ini, dalam upaya menciptakan kedamaian, Melin (2016, p. 1) mengungkapkan:

Understanding the roles these actors play and the outcomes of their efforts will enable us to encourage future involvement where opportunities for engagement might otherwise be 
missed. Increasing our knowledge and understanding of the corporate role in promoting peace generates important evidence useful for encouraging positive corporate involvement into the future, as well as useful tools for evaluating conflict resolution efforts.

Temuan menarik tentang resolusi konflik yang dilakukan peserta didik dalam penelitian ini adalah adanya upaya mengkolaborasikan kedua gaya kognitif yang mengarah pada kedamaian pribadi, tampak dalam pernyataan sebagai berikut:

"Ketidakdamaian yang saya alami ketika menjalani sebuah kehidupan menjadikan saya

Tabel-2 Pendapat Partisipan tentang Makna, Ciri, dan Tanggung Jawab Memelihara Kedamaian*

\begin{tabular}{|c|c|c|c|}
\hline No. & Makna & Ciri & Tanggung jawab \\
\hline 1. & $\begin{array}{l}\text { Terjalin hubungan yang harmonis } \\
\text { dengan guru maupun teman sekelas, } \\
\text { tidak ada perasaan tertekan, dan } \\
\text { tidak terbebani dengan hal apapun } \\
\text { (P1) }\end{array}$ & & \\
\hline 2. & $\begin{array}{l}\text { Memiliki kehidupan yang selaras } \\
\text { dengan lingkungan. Ketika ada } \\
\text { sedikit rasa takut, khawatir, dan } \\
\text { cemas, maka dikatakan tidak damai } \\
\text { (P4) }\end{array}$ & & $\begin{array}{l}\text { Dimulai dari diri sendiri, dengan tidak } \\
\text { berburuk sangka, saling menghargai, } \\
\text { dan jujur. Setelah kita berdamai } \\
\text { dengan diri sendiri baru kita dapat } \\
\text { berdamai dengan orang lain. (P4) }\end{array}$ \\
\hline 3. & $\begin{array}{l}\text { Orang tidak menghakimi orang lain } \\
\text { ataupun men-judge yang membuat } \\
\text { perselisihan di antara orang tersebut } \\
\text { (P5) }\end{array}$ & $\begin{array}{l}\text { Tentram, tidak ada perselisihan, } \\
\text { tidak ada perpecahan, saling } \\
\text { memaafkan, tidak ada } \\
\text { kebencian, adil }\end{array}$ & $\begin{array}{l}\text { Mencegah terjadinya pertikaian, } \\
\text { perselisihan, mendamaikan yang } \\
\text { berselisih, pemaaf }\end{array}$ \\
\hline 4. & $\begin{array}{l}\text { Saling percaya dan tercipta ciri-ciri } \\
\text { damai (P7) }\end{array}$ & $\begin{array}{l}\text { Harmonis, saling perhatian, } \\
\text { saling menghargai, menjaga } \\
\text { harga diri, tidak ada kekerasan }\end{array}$ & $\begin{array}{l}\text { Menjaga kedamaian dengan } \\
\text { silaturahmi sehingga terjalin } \\
\text { hubungan yang dekat dan muncul } \\
\text { rasa saling menghargai, saling } \\
\text { menjaga, saling membantu secara } \\
\text { konsisten. }\end{array}$ \\
\hline 5. & $\begin{array}{l}\text { Menghormati diri sendiri dan orang } \\
\text { lain tanpa terkecuali (P8) }\end{array}$ & & \\
\hline 6. & $\begin{array}{l}\text { Keadaan dimana kondisi dan situasi } \\
\text { yang tenteram, tidak ada konflik, } \\
\text { dan terpenuhinya segala kebutuhan } \\
\text { (P9) }\end{array}$ & $\begin{array}{l}\text { Sehat, kebutuhan terpenuhi, } \\
\text { tidak ada yang dirugikan, } \\
\text { tenang dan tenteram, saling } \\
\text { menghargai, tolong menolong } \\
\text { dalam kebaikan }\end{array}$ & $\begin{array}{l}\text { Melakukan kegiatan yang tidak } \\
\text { menimbulkan konflik, berbuat baik, } \\
\text { tidak melakukan kekerasan, berpikir } \\
\text { sebelum bertindak }\end{array}$ \\
\hline 7. & $\begin{array}{l}\text { Situasi dimana kita bisa } \\
\text { mengekspresikan sesuatu secara } \\
\text { bebas, namun tidak bertentangan } \\
\text { dengan norma (P10) }\end{array}$ & & \\
\hline 8. & $\begin{array}{l}\text { Keadaan dimana kita merasa } \\
\text { nyaman dan menikmati keadaan } \\
\text { tersebut dengan sepenuh hati tanpa } \\
\text { ada perasaan resah, tertekan, } \\
\text { ataupun terbebani }(\mathrm{P} 11, \mathrm{~L} 6))\end{array}$ & $\begin{array}{l}\text { Hati merasa tenang, pikiran } \\
\text { bebas, bebas dari tekanan, } \\
\text { menikmati keadaan, nyaman } \\
\text { (P11) } \\
\text { Nyaman, tenteram, saling } \\
\text { melindungi (L6) }\end{array}$ & $\begin{array}{l}\text { Tidak mempersulit segala sesuatu } \\
\text { yang harus kita hadapi, nikmati apa } \\
\text { yang harus dilakukan, kondisikan diri } \\
\text { kita dalam kenyamanan yang kita } \\
\text { inginkan }\end{array}$ \\
\hline 9. & $\begin{array}{l}\text { Saling menghargai dan nyaman di } \\
\text { suatu keadaan (P12) }\end{array}$ & $\begin{array}{l}\text { Tidak ada konflik, saling jaga } \\
\text { perasaan, rukun }\end{array}$ & \\
\hline 10. & $\begin{array}{l}\text { Keadaan dimana perasaan dan } \\
\text { pikiran seseorang berada dalam }\end{array}$ & $\begin{array}{l}\text { Pikiran tenang, fokus, ramah, } \\
\text { disukai banyak orang }\end{array}$ & \\
\hline
\end{tabular}

tahu akan makna hidup yang sebenarnya. Tidak semua orang dalam perjalanan hidupnya akan berjalan mulus, pasti kita semua akan melewati susah, perih, dan stresnya hdup. Di balik canda tawa dan senyum manis yang ditampilkan seseorang belum tentu orang itu tidk mempunyai masalah. Hanya saja, orang itu berusaha untuk tidak menunjukkan kesedihan dan ketaknyamanannya" (L13).

Perspektif Kedamaian: Makna, Ciri, dan Tanggung Jawab Memelihara Kedamaian

Hasil analisis terhadap transkrip wawancara, diperoleh informasi yang beragam terkait makna, ciri, dan tanggung jawab dalam memelihara kedamaian. 
PEDAGOGIA : Jurnal Ilmu Pendidikan

\begin{tabular}{|c|c|c|c|}
\hline No. & Makna & Ciri & Tanggung jawab \\
\hline & $\begin{array}{l}\text { keadaan yang nyaman dan tidak } \\
\text { resah }(\mathrm{P} 13)\end{array}$ & & \\
\hline 11. & $\begin{array}{l}\text { Suatu kondisi dimana hati dan } \\
\text { lingkungan terdapat relasi yang } \\
\text { baik (P 14) }\end{array}$ & $\begin{array}{l}\text { Hati tenteram, pikiran tenang, } \\
\text { lingkungan cocok }\end{array}$ & \\
\hline 12. & $\begin{array}{l}\text { Ketika teman dan guru dapat } \\
\text { memahami setiap pribadi yang } \\
\text { memiki keunikan masing-masing } \\
(\mathrm{P} 15)\end{array}$ & & \\
\hline 13. & $\begin{array}{l}\text { Suatu keadaan dimana ketika kita } \\
\text { berada di suatu tempat untuk } \\
\text { melakukan sesuatu, hati merasa } \\
\text { senang dan tenang (P17) }\end{array}$ & & \\
\hline 14. & $\begin{array}{l}\text { Perasaan tenang, aman, dan bahagia } \\
\text { (P18) }\end{array}$ & Teratur, tentram, dan bahagia & $\begin{array}{l}\text { Dengan tidak berbuat kekacauan dan } \\
\text { tidak melakukan keburukan pada } \\
\text { orang lain. }\end{array}$ \\
\hline 15. & $\begin{array}{l}\text { Suatu keadaan yang nyaman, tanpa } \\
\text { ada perselisihan dan permusuhan } \\
\text { dalam harmoni kehidupan antar } \\
\text { manusia (P 19, L9) }\end{array}$ & $\begin{array}{l}\text { Keseimbanan hak asasi, saling } \\
\text { menghormati dan menghargai, } \\
\text { tolong menolong, hidup } \\
\text { merdeka dan mengatur diri } \\
\text { sendiri (P19) } \\
\text { Teratur, disiplin, transparan, } \\
\text { demokratis, saling } \\
\text { menghormati, bebas } \\
\text { berekspresi, bebas beribadah } \\
\text { (L9) }\end{array}$ & $\begin{array}{l}\text { Memelihara suatu kedamaian (P19) } \\
\text { Memperkuat akar perdamaian dengan } \\
\text { memulai damai dengan dri sendiri, } \\
\text { damai dalam menyelesaikan konflik, } \\
\text { jangan berbuat keributan, minta } \\
\text { bantuan penyelesaian konflik kepada } \\
\text { pemimpin, tokoh agama, tokoh adat, } \\
\text { tokoh masyarakat (L9, L13 }\end{array}$ \\
\hline 16. & $\begin{array}{l}\text { Hidup tanpa ada penekanan dari } \\
\text { orang lain (P 20) }\end{array}$ & $\begin{array}{l}\text { Bebas mengekspresikan diri, } \\
\text { tidak ada tekanan dari pihak } \\
\text { lain, hidup berdampingan, tidak } \\
\text { ada topeng dalam berperilaku }\end{array}$ & $\begin{array}{l}\text { Kedamaian merupakan tanggng } \\
\text { jawab semua }\end{array}$ \\
\hline 17. & $\begin{array}{l}\text { Suasana seseorang yang merasa } \\
\text { tenteram, apa yang terjadi sesuai } \\
\text { dengan yang diinginkan sebenarnya } \\
\text { (P21) }\end{array}$ & Saling mendukung, tenteram & \\
\hline 18. & $\begin{array}{l}\text { Bukan diam atau tidak bising, tetapi } \\
\text { lebih ke perasaan hati yang tenang, } \\
\text { gak ada permasalahan yang } \\
\text { mengganggu ketenagan hati (L1) }\end{array}$ & $\begin{array}{l}\text { Tenang ketika ada } \\
\text { permasalahan, banyak teman, } \\
\text { sering ketawa, nggak banyak } \\
\text { tugas dan tanggungan }\end{array}$ & $\begin{array}{l}\text { Selalu berpikir positif, hadapi } \\
\text { masalah jangan mengeluh }\end{array}$ \\
\hline 19. & $\begin{array}{l}\text { Rasa senang, aman, dan nyaman } \\
\text { (L2) }\end{array}$ & $\begin{array}{l}\text { Kondusif, saling menghormati } \\
\text { dan menghargai, cinta dan kasih } \\
\text { saying }\end{array}$ & $\begin{array}{l}\text { Berusaha berbuat baik dan berharap } \\
\text { orang lain pun berbuat baik }\end{array}$ \\
\hline 20. & $\begin{array}{l}\text { Nyaman dan aman, tidak ada } \\
\text { perseteruan dan konflik secara } \\
\text { pribadi maupun sosial (L4) }\end{array}$ & $\begin{array}{l}\text { Bahagia, aman, nyaman, tidak } \\
\text { ada konflik }\end{array}$ & $\begin{array}{l}\text { Meminta dan memberi maaf kepada } \\
\text { orang lain, berpikir positif, menjaga } \\
\text { emosi, dan selalu tersenyum }\end{array}$ \\
\hline 21. & $\begin{array}{l}\text { Suatu kondisi dimana hubungan } \\
\text { kita dengan orang lain berjalan } \\
\text { baik-baik saja, tidak memiliki rasa } \\
\text { tidak suka, benci, dan dendam pada } \\
\text { orang lain, begitu juga sebaliknya } \\
\text { (L5) }\end{array}$ & $\begin{array}{l}\text { Saling bantu, tegur sapa, } \\
\text { berhubungan baik, tidak malu } \\
\text { mendahului berbicara }\end{array}$ & $\begin{array}{l}\text { Tanggung jawab bersama semua } \\
\text { pihak }\end{array}$ \\
\hline 22. & $\begin{array}{l}\text { Keadaan harmonis antar manusia, } \\
\text { tidak ada konflik dan tekanan pihak } \\
\text { lain }(\mathrm{L} 7, \mathrm{P} 8) \text { ) }\end{array}$ & $\begin{array}{l}\text { Tidak ada konflik, tekanan, dan } \\
\text { iri hati }\end{array}$ & \\
\hline 23. & $\begin{array}{l}\text { Waktu dimana diri dapat } \\
\text { mengendalikan emosi, ada } \\
\text { sinkronisasi antara pikiran, sikap, } \\
\text { dan hati (L8) }\end{array}$ & & \\
\hline 24. & $\begin{array}{l}\text { Ketika seseorang merasakan } \\
\text { kebebasan dan kebahagiaan dalam } \\
\text { hidupnya (L13) }\end{array}$ & Tentran, bersemangat, bebas & \\
\hline 25. & $\begin{array}{l}\text { Ketenangan perasaan yang dialami } \\
\text { dikarenakan hati nurani sudah } \\
\text { sejalan dengan pikiran, perkataan, } \\
\text { dan perbuatan serta kenyataan }\end{array}$ & $\begin{array}{l}\text { Mensyukuri apa yang dimiliki, } \\
\text { tidak menyembunyikan dosa, } \\
\text { mengamalkan kebaikan, } \\
\text { bahagia saat berinteraksi }\end{array}$ & $\begin{array}{l}\text { Senantiasa berihtiar dan beriman } \\
\text { dalam kehidupan karena kebahagiaan, } \\
\text { perdamaian, maupun nikmat } \\
\text { sesungguhnya diperuntukkan bagi }\end{array}$ \\
\hline
\end{tabular}




\begin{tabular}{|c|c|c|c|}
\hline No. & Makna & Ciri & Tanggung jawab \\
\hline & (L14) & $\begin{array}{l}\text { dengan orang lain, bahagia } \\
\text { melihat orang lain tersenyum, } \\
\text { ikhlas, tidak ada orang yang iri } \\
\text { hati, berlaku jujur }\end{array}$ & orang beriman \\
\hline 26. & $\begin{array}{l}\text { Jangan ada orang yang } \\
\text { mengganggu hidupku (L15) }\end{array}$ & & \\
\hline 27. & $\begin{array}{l}\text { Situasi tenang dan aman antara } \\
\text { sesama dan lingkungan (L18) }\end{array}$ & $\begin{array}{l}\text { Aman dan tidak terbebani } \\
\text { situasi }\end{array}$ & $\begin{array}{l}\text { Percaya diri dan mampu menjaga } \\
\text { pikiran dengan situasi yang dihadapi }\end{array}$ \\
\hline
\end{tabular}

Tabel 2 mengisyaratkan bahwa sebagian besar perserta didik memaknai kedamaian dalam perspektif positif. Hanya sekira $25 \%$ peserta didik yang memaknai kedamaian dala perspektif negatif. Temuan penelitian ini sejalan dengan hasil penelitian McLernon \& Cairns (2006) bahwa persepsi peserta didik tentang damai yang semula adalah ketiadaan konflik, yang lebih cenderung pada perspektif negatif, maka pada saat remaja konsep damai akan menjadi cenderung kepada kebebasan dan keadilan. Hal yang menarik dari hasil penelitian ini adalah bahwa definisi damai tidak hanya terbatas pada perspektif individual, namun juga telah masuk dalam kelompok dan lingkungan bahkan transedental (periksa pendapat L14 pada Tabel 2). Peserta didik mulai menyadari bahwa kedamaian tidak hanya untuk diri sendiri namun juga bagi kelompok dan lngkungan dari mulai keluarga sampai dengan lingkungan yang lebih luas.

Dalam penelitian ini tidak ada peserta didik yang mengartikan kedamaian sebagai lawan dari peperangan sebagaimana ditemukan dalam penelitian sebelumnya (McLernon \& Cairns, 2006; Hakvoort \& Oppenheimer, 1998). Hal ini diduga terjadi karena peserta didik di Indonesia tidak mengenal, mengalami, dan merasakan peristiwa perang secara langsung. Perang hanya mereka kenal melalui sejarah atau perang di negara lain melalui tayangan berita di televisi. Atas dasar itu adalah wajar apabila perspektif mereka tentang kedamaian tidak ada satupun yang menyandingkannya dengan peperangan. Mereka lebih cenderung ke konsep positive peace, seperti saling menyayangi, menghormati, menghargai, kerjasama, kesetaraan, demokrasi dan harmoni. Temuan ini diperkuat oleh pandangan Galtung (1967) bahwa pada usia 10 tahun mulai konstruk konsep kedamaian yang positif dan aktif. Peserta didik kelas III SMA umumnya berusia di atas delapan tahun lebih tua dari usia dimulainya konsep kedamaian positif yang prediksi Galtung.

Tampaknya, keragaman pemahaman tentang makna dan tanggung jawab memelihara kedamaian ini dapat ditelusuri dari penjelasan Taheri \& Dehghan (2014, p. 56) sebagai berikut.

Although the word "PEACE" has a clear meaning for most people, 'peaceful act' and 'peaceful individual' can have different interpretations. In conflict to the common assumption, the state of the peaceful person is not one we can achieve only through good deeds. This state is obtained through perceptions that result in making peace with God, with the universe, with one's self, and with the others. The peaceful individual has no conflict with any of them. Consequently, the individual's thoughts, actions and words are also formed on the basis of this internal and multilateral peace. When a person is striving toward conflicts, their being does not work in integrity; hence, the brain orders the secretion of poisonous chemical hormones. In other words, the conflict factor is one of the poisonous factors that harms 
human's health and takes away their inner peace. It is one of the factors causing mentosomatic diseases.

Tampak bahwa kedamaian dipersepsi secara beragam dan mencakup multi dimensi, termasuk kedamaian dengan Tuhan. Pendapat Taheri \& Dehghan ini memberikan inspirasi yang berharga untuk memahami esensi kedamaian yang sesungguhnya.

\section{Prospek Kedamaian di Masa Depan}

Hasil analisis terhadap transkrip wawancara terkait prospek kedamaian di masa depan menurut peserta didik, disajikan pada tabel berikut.

Tabel-3 Pendapat Partisipan tentang Prospek Kedamaian di Masa Depan

\begin{tabular}{|c|c|}
\hline No. & Prospek Kedamaian di Masa Depan*) \\
\hline 1. & $\begin{array}{l}\text { Tercipta rasa damai dimana semua orang merasa bahagia, aman dan tenteram tanpa ada beban atau tekanan } \\
\text { apapun serta merasakan kebahagiaaan dalam hidup serta tiadak ada pertengkaran (P2) }\end{array}$ \\
\hline 2. & Guru berwibawa, kasih sayang terhadap pesertadidik, pengembang pembelajaran inovatif (P9) \\
\hline 3. & Makin dewasa semakin besar peluang untuk memperoleh kedamaian (P13) \\
\hline 4. & $\begin{array}{l}\text { Kedamaian semakin memprihatinkan karena akan tumbuhnya paham egoisme dan berkurangnya nilai-nilai } \\
\text { kebersamaan (P14) dan maraknya kriminalisasi (L6) }\end{array}$ \\
\hline 5. & $\begin{array}{l}\text { Tergantung kepada individu sendiri bagaimana caranya individu menyikapi kehidupannya dan melakukan hal- } \\
\text { hal yang baik bagi sekitarnya. Apabila ingin menikmati kedamaian di masa depan makan tanamkanlah } \\
\text { kedamaian dalam diri seperti saling menghargai hak asasi, menyayangi, dan tolong menolong. (P190 }\end{array}$ \\
\hline 6. & Akan ada saatnya kedamaian itu lahir, akan tetapi untuk saat ini masih dalam proses (L3) \\
\hline 7. & $\begin{array}{l}\text { Menciptakan kedamaian tidak bisa dilakukan oleh perseorangan melainkan harus dibangun bersama. Jangan } \\
\text { mencari masalah, bersikap dan berpikir positif, jangan menjadikan hal kecil menjadi masalah besar (L8) }\end{array}$ \\
\hline 8. & $\begin{array}{l}\text { Manusia tidak lagi mempedulikan warna kulit, ras, agama, bahkan negara. Manusia secara bersama-sama } \\
\text { menciptakan dunia yang lebih baik tanpa perang dengan melupakan egonya. (L9) }\end{array}$ \\
\hline 9. & Merubah dunia ini menjadi lebih baik lagi (L14) \\
\hline 10. & $\begin{array}{l}\text { Akan banyak dirasakan oleh semua orang di dunia. Kedamaian akan menunjukkan harapan setiap orang untuk } \\
\text { bisa menghadapi sesuatu (L18) }\end{array}$ \\
\hline
\end{tabular}

Tabel 2 mengindikaksikan bahwa prospek kedamaian di masa depan, menurut pandangan peserta didik, terbelah menjadi dua kubu. Sebagian besar peserta didik optimis bahwa masa depan itu akan semakin damai dan menjelaskan bagaimana seharusnya peran guru dalam membangun kedamaian. Sedangkan yang lainnya merasa pesimis bahwa kedamaian di masa depan akan sulit diraih karena kenyataan sekarang manusia makin egois, kurang kebersamaan, dan banyak kriminalitas. Banyaknya peserta didik yang optimis untuk kedamaian di masa depan, sesuai dengan pendapat Megoran (2011, p. 187) bahwa rekonseptualisasi kedamaian di masa depan menjadi lebih positif dan perlunya komitmen untuk mewujudkan dan memelihara kedamaian. Terkait dengan komitmen dalam memelihara kedamaaian, kini muncul berbagai riset terkait geographical peace yakni aktivis dan gerakan kedamaian pada suatu wilayah dan geohistory of peace yakni apa dan bagaiana meningkatkan kedamaian dalam wilayah tersebut.

Hal lain yang menarik dari temuan penelitian ini adalah terkait pemikiran peserta didik tentang kedamaian di masa depan yang tidak hanya fokus pada lingkungan sekolah, melainkan sudah berpikir bagaimana membangun kedamaian dunia yang dimulai dari kedamaian pribadi yang mengutamakan kesamaan dibanding perbedaan dalam hal ras, agama, bangsa, budaya dan lain-lain. Pemikiran tersebut sejalah dengan gerakan para peneliti intercultural untuk berkontribusi membuat dunia menjadi tempat lebih baik sebagai salah satu raksi terhadap kelelahan dalam memandang kedamaian dunia saat ini. Mereka mengubah perspektif "Research Culture of War" dalam arti mendominasi dan memeras orang lain serta menekankan perbedaan ketimbang kesamaan dalam 
relasi dengan orang lain ke perspektif "Thou Shalt not Kill" yang lebih terbuka menerima ketimbang mengendalikan dan meluluhkan orang lain (Kim, 2014, p.3) dan lebih mengutamakan jejaring dalam membangun kedamaian (Laliberte, In Press, p. 1)

\section{E. SIMPULAN DAN REKOMENDASI}

Peristiwa di sekolah yang menurut peserta didik dikonotasikan tidak damai, konteksnya sebagian besar terkait dengan guru dan sesama peserta didik. Perlakuan kurang mendidik dari guru dalam bentuk verbal dan hukuman fisik selama proses pembelajatan dan di luar kelas, merupakan peristiwa yang dinyatakan tidak damai oleh peserta didik. Konflik antar peserta didik berbentuk bullying dan konflik personal. Dalam resolusi konnflik dengan guru, mereka umumnya memilih bersikap pasif dan menarik diri. Sedangkan konfik dengan teman selain ada yang pasif juga ada yang berani konfrontasi.

Peserta didik memaknai damai lebih cenderung dalam perspektif positif dan mengutanakan kedmaain dengan diri sendiri, orang lain, lingkungan dan bahkan dengan Tuhan. Prospek kedamaian ke depan kendati ada yang pesimistik, namun umumnya mereka yakin bahwa dengan usaha bersama kekdamaian dunia akan tercapai. Pemikiran mereka tentang kedamaian tidak hanya di sekolah, melainkan sudah jauh menyangkut kedamaian lingkungan sekitar, negara, bahkan kedamaian dunia.

Implikasi bagi pendidikan kedamaian di sekolah adalah guru harus memimpin dan menjamin terciptanya keadilan sosial dan perdamaian di kelas dan sekolah. Guru melalui pembelajaran bidang studi, seyogiyanya mengembangakan kompetensi damai pada peserta didik terutama melalui tutur bahasa dan perilaku yang mendidik yang menyentuh pada mindful learning sebagai sarana menciptakan lingkungan sekolah yang damai kondusif bagi peserta didik.

\section{F. REFERENSI}

Berger, R., Benatov, J., Abu-Raiya, H., Tadmor, C. T. (In Press). Reducing prejudice and promoting positive intergroup attitudes among elementary-school children in the context of the Israeli-Palestinian conflict. Journal of School Psychology xxx (2016) xxx-xxx

Buckner, Kermit G. \& Richard A. Flanary (1996). Protecting Your School and Students: The Safe Schools Handbook. North Dakota State Univ Lib

Cross D., et al. (2011). National Safe Schools Framework: Policy and practice to reduce bullying in Australian schools. International Journal of Behavioral Development 35(5) 398-404

Syrjäläinen, et al. (2015). Safe School Day According to the Young. Journal Young 23(1) 59-75

Galtung, J. (1967). Theories of peace: A synthetic approach to peace thinking. Oslo: International Peace Research Institute.

Honkasilta, J. , Vehkakoski, T., Vehmas, S. (2016). The teacher almost made me cry' Narrative analysis of teachers' reactive classroom management strategies as reported by students diagnosed with ADHD. Teaching and Teacher Education. 55 (2016) 100-109

Joseph, J. (2012). How the schooling environment shapes the consciousness of scholars towards peace and war. Procedia - Social and Behavioral Sciences 55 ( 2012 ) 697-706.

Kartadinata, S. (2014). Pendidikan kedamaian dan pendidikan untuk kedamaian. Bandung: UPI Press. 
Kartadinata, S., Affandi, I., Wahyudin, D., \& Ruyadi, Y. (2015). Pendidikan kedamaian. Bandung: Rosda.

Katsos, J. E. \& Fort, T. L (In Press). Leadership in the promotion of peace: Interviews with the 2015 Business for Peace honorees. Business Horizons (2016) $\mathrm{xxx}$, $\mathrm{xxx}-\mathrm{xxx}$

Kim, M. (2012). World peace through intercultural research: From a research culture of war to a research culture of peace. International Journal of Intercultural Relations 36 (2012) 3-1

Kirton, M. J. (2003). Adaption-innovation: In the context of diversity and change. New York: Routledge.

Kolk, A. \& Lenfant, F. (In Press). Hybrid business models for peace and reconciliation. Business Horizons. (2016) $\mathrm{xxx}, \mathrm{xxx}$ - $\mathrm{xxx}$

Laliberte, N. (In Press). 'Peace begins at home': Geographic imaginaries of violence and peacebuilding in northern Uganda. Political Geography xx (2016) xx-xx.

McLeod, J. A (2014). Peaceful pedagogy: Teaching human rights across the curriculum. Procedia - Social and Behavioral Sciences 152 ( 2014 ) $1225-123$

McLernon, F.\& Chairn, E. (2006). Children's attitudes to war and peace: When a peace agreement means war. International Journal of Behavioral Development, 30 (3), 272-279

Mendoza, G., Valenzuela, B., \& Guillen, M. (2013). Peace project from transdisciplinary dimension. Procedia - Social and Behavioral Sciences 106 ( 2013 ) 2022 - 2027

Min-Sun KimHonkasilta, J., Vehkakoski, T. , Vehmas, S. (2016) 'The teacher almost made me cry' Narrative analysis of teachers' reactive classroom management strategies as reported by students diagnosed with ADHD. Teaching and Teacher Education 55 (2016) 100-109.

Navaro-Castro, L. \& Nario-Galace, J. (2008). Peace education: A pathway to a culture of peace. Quezon City: Center for Peace Education, Miriam College.

Reardon, B. A. (1988). Comprehensive peace education. New York. Teacher College. Columbia University.

Reardon, B. A. (1993). Women and peace: Feminist visions of global security. Albany: University of New York Press.

Rettberg, A. (In Press). Need, creed, and greed: Understanding why business leaders focus on issues of peace. Business Horizons (2016) xxx, $\mathrm{xxx}-\mathrm{xxx}$

Taheri, M. A. \& Deghan, M. (2014). Definition of peace and it different types of approach by Halqeh mysticism. Procedia - Social and Behavioral Sciences 114 ( 2014 ) 5661.

Tosuna, O. (2014). Anger Management of Students for a Peaceful School Environment: The Group Studies. Procedia - Social and Behavioral Sciences 159 ( 2014 ) 686-690 